\title{
A Strategic Approach to Onsite Learning in the Era of SARS-Cov-2
}

\author{
Michael Agyemang Adarkwah ${ }^{1}[$
}

Received: 18 February 2021 / Accepted: 26 April 2021 / Published online: 7 May 2021

(c) The Author(s), under exclusive licence to Springer Nature Singapore Pte Ltd 2021

\begin{abstract}
The COVID-19 pandemic disrupted all forms of social life, including the education sector. As part of the efforts to keep the virus at bay, onsite instruction was suspended in 188 countries across the globe, jeopardizing the educational goals of over $91 \%$ of the world's student population. Online learning emerged as an ultimate solution to the disruption caused by the COVID-19 pandemic. The main challenge of most developing countries, especially in Sub-Saharan Africa, is to ensure effective online learning across all levels of education. The lack of funds, infrastructure, effective e-learning systems, ICT gadgets, and other challenges hindered the online learning in most developing countries from achieving its intended goal. With the realization that the COVID-19 may not die out soon and the prospect of a vaccine, Ghana, like many countries, resumed onsite instruction in early 2021. The study employed a phenomenological approach through personal interviews to explore the experiences of 20 tertiary students who were the first batch of students to be part of the temporal resumption of tertiary education in Ghana. From the analysis, it was observed that universities educated their staff and students on COVID19. Nonetheless, there were contextual challenges with; the provision of personal protective equipment (PPEs), engagement in digital learning, parent-teacher collaboration, psychological health service, and course completion. The study discusses school preparedness plan of universities for resumption and draws from the literature to outline ten strategic ways to reopen schools.
\end{abstract}

Keywords Online learning · Onsite learning $\cdot$ COVID-19 $\cdot$ Distance education $\cdot$ Ghana education

\section{Introduction}

The novel coronavirus (SARS-Cov-2), also known as the COVID-19 pandemic is still unfolding nearly after a year of its discovery in the city of Wuhan [22, 67, 92]. The World Health Organization on January 30, 2020 announced that the SARS-Cov-2 "now meets the criteria for a Public Health Emergency of International Concern", and officially declared it as a global pandemic on March 11, 2020 [92]. In response to the COVID-19 pandemic, social distancing and stay-at-home guidelines were advocated as primary key measures in battling the pandemic [93] against the background of persistent education inequality and crisis [70]. Recognized as perhaps the biggest blow to the world's economy, the COVID-19 pandemic has resulted in an unprecedented disruption in all spheres of education, especially with

Michael Agyemang Adarkwah

adarkwahmichael1@gmail.com

1 Southwest University, Tianzhu Street, Beibei District No. 2, Chongqing, China the introduction of social-distancing norms [74]. Notably, in-person teaching, simulation laboratories, and conferences were cancelled [21].

In 188 countries across the globe, education institutions across all levels (preprimary, primary, secondary, and higher education) have shut down, affecting the education careers of more than $91 \%$ of the student population in the world [87]. The educational challenges created by the COVID19 pandemic has made it difficult for courses that thrive on in-person laboratory teaching to be delivered [53]. The crisis resulting from the COVID-19 triggered an outbreak of online learning [98]. However, the usage of e-learning systems, a web-based software platform for online learning [85], has become the main challenge of most institutions both in developed and developing countries [5]. Almaiah et al. added that the challenges by educational institutions are a result of the digital divide in developing countries. They further stated that developing countries experience a $45 \%$ failure in e-learning projects, with $40 \%$ partial failures, and only $15 \%$ success rate. In this pandemic era, many 
universities transitioned to an online learning modality without necessarily focusing on online pedagogy [26].

In Ghana, the emergent transition to online learning has not been smooth [1]. The e-learning approach demands a quality internet connection and mobile/computer gadgets [36], which are inadequate in Ghana [9]. Institutions which are poorly managed, and with socially disadvantaged students who have limited access to internet and technology find it difficult to respond to student's needs, and their inability to engage in the e-learning process [15]. Although Ghana is still wary of lifting the bans on school operations to control the spread of the virus, it has partially resumed schools for final year students at the Junior High School (JHS) and Senior High School (SHS) to complete their statewide exams, and hope to resume tertiary education in early $2021[16,60]$. There are many educational institutions in the world that also plans to resume the traditional mode of instruction in classrooms. Thus, onsite learning across many countries is on the brink of realization with promising vaccine development $[55,57]$. But the greatest questions to answer are,"Are vaccines going to be effective and safe?", and "how long is immunity through such vaccine going to be effective?" [14], p. 357). Major [57] calls for educators to prepare fully for both onsite and online learning. Everyone's goal is to make a quick and safe reopening of schools a priority because of the benefits of in-person learning [20]. To date, there are limited studies $[2,5,8]$ that address strategic approaches to onsite learning in the era of COVID-19 pandemic, especially in the context of a developing country like Ghana. In this paper, an appropriate strategic approach to resume onsite learning is discussed using Ghana as a case study. The study discusses onsite learning in Ghana in the pre-pandemic period, the challenges of the online learning post COVID-19, and provides a COVID-19 comeback model for onsite learning.

\section{Background Context}

Ghana recorded its first case of the SARS-Cov-2 on March 12 , and the government has since then announced a series of sweeping measures to combat the virus, such as closing of borders and banning of mass gatherings [61]. As of 15th June 2020, Ghana was only second to Nigeria in terms of West African countries greatly impacted by the COVID-19, remaining third in WHO African regions in terms of the number of cumulative cases [88]. In light of the COVID19 pandemic, Ghana, like many countries, also suspended onsite instruction. The lockdown of schools affected 9.2 million learners in Ghana from kindergarten (KG) to SHS, and 500,000 tertiary students [60]. During the pre-pandemic period in Ghana, students were being instructed in classrooms across all levels of education with few adults, workers, and some students enrolled in Distance Education (DE). The discontinuity in learning put the educational careers of students in jeopardy, especially final year students at the secondary and tertiary level. Under this circumstance, the education sector was faced with myriad of challenges which were never anticipated. To enable teaching and learning to continue, the Ministry of Education was forced to replace the traditional mode of instruction with online learning and DE methods. Nonetheless, the education system of Ghana was stagnant in terms of online learning until it was prompted by the COVID-19 pandemic [1]. Hence, the online learning mode of instruction was described as a "challengeridden online learning" by the National Union of Ghana Students (NUGS). The NUGS cited the absence of a properly laid out framework for implementation of online learning, inadequate bundle incentives, and resources as some of the contributing factors making the online instruction difficult. Also, needy students who lacked ICT gadgets and money to buy internet bundle were left out of the online learning instruction [102]. Adarkwah [1] opined that online learning in Sub-Saharan Africa is a great challenge. Only a handful of teachers can instruct online in Ghana [37]. Based on the experiences of tertiary students, the online learning is fraught with myriad of challenges [1]. The difficulties in the online learning give an evidence why Ghana plans to resume onsite learning in early $2021[65,100]$.

\section{The Present Study}

The COVID-19 pandemic exposed the inequality in Ghana education [61]. For a long time, the indefinite closure of schools has been the reality of many students in the high school due to lack of educational infrastructure at the northern part compared to the affluent south. Aside the regional disparities, social class is also a determinant factor on the quality of education, with wealthier parents sending their wards to "good" schools (primary and junior high level). Adarkwah [1] opined that the online learning in Ghana is fraught with a lot of challenges including the inability of needy students to receive instruction, complete their assignments and exams. The poor/needy students could not engage in the online learning in Ghana due to lack of funds and resources. High cost of bundle and ICT gadgets made it impossible for some students to continue their education. Online learning is effective in developed countries and not in developing countries [2]. With the realization that the COVID-19 pandemic will not die out soon, the prospect of a potent vaccine, and the ineffectiveness of the e-learning, Ghana prepares to resume onsite learning. Ghana witnessed a drastic drop in the number of COVID-19 in late 2020. The total number of confirmed cases in Ghana is 52,274, with 325 deaths, 886 active cases, and 76 new cases on December 
8, 2020 [33]. As at February 2021, Ghana, like many countries, are still not out of the pandemic crisis. Since it was projected that the COVID-19 might thrive for long, even in the advent of a vaccine [54], many countries and institutions are gradually learning to accommodate to the "new normal" of living with the SARS-Cov-2. It is estimated that when the SARS-Cov-2 dies down, there will be pressure on school leaders, teachers, and students [7]. Thus, instructors and students will have limited time to recover all the time "lost". Instructors would be forced to teach many topics in a short space of time, and students would have limited time to assimilate all what is being taught. Additionally, some universities and schools temporarily resumed school on January 15, 2021. Because of limited physical capacities, universities are operating on a "double-track" approach (first batch of students would complete the semester in April and would be replaced by a second batch who stayed at home since the temporal resumption). However, with the rising cases in Ghana and reports of students getting infected by the COVID-19, the Ghana National Association of Teachers (GNAT) has advocated for a re-closure of schools at all levels [35]. This has called for the need to address suitable contextual approaches to onsite learning for effective instruction. The present study draws from qualitative data from tertiary students and extant literature to suggest ten strategic ways to resume permanent onsite learning in schools, with a focus on tertiary level education. The study adds to the theoretical knowledge on the impact of the COVID-19 pandemic on education, online learning, and offer insights on how to come back from the COVID-19 pandemic for effective onsite learning. Specifically, based on respondents views on resumption measures at their universities, the paper put forth ten contextual approaches to onsite learning as Ghana resumes all levels of education in early 2021 [16, 65] (Fig. 1).

\section{Style of Onsite Learning in Ghana}

Traditionally, instruction of students from kindergarten to tertiary is onsite (face-to-face) across public and private schools in Ghana. At the tertiary level, there are distance learning programs for mature students or students who for some reasons cannot attend the physical class. The Ghana Education Service (GES) together with the National Council for Curriculum and Assessment (NACCA), National Council for Tertiary Education (NCTE), and the National Teaching Council (NTC) are responsible for structuring a standardbased curriculum for schools. Instructors teach based on the developed curriculum for schools. At all levels, instructors use textbooks, self-designed handouts/pamphlets for classroom instruction. However, at the tertiary level, Information Communication Technology (ICT) gadgets such as projectors and simulations/PowerPoint presentations are used as teaching aids for students to grasp the central concept of what is being taught. Also, there are few exchanges of email conversations between lecturers and students at the university level. In some schools, there are libraries and ICT laboratories where students are supposed to spend some time for their self-study. Also, there are "extra classes" for students who can afford for additional hours of instruction in some educational institutions in the country. Exams and classroom tests are based on the textbooks used for instruction at the basic (primary to junior high school) and secondary level while this may not necessarily be the case at the tertiary

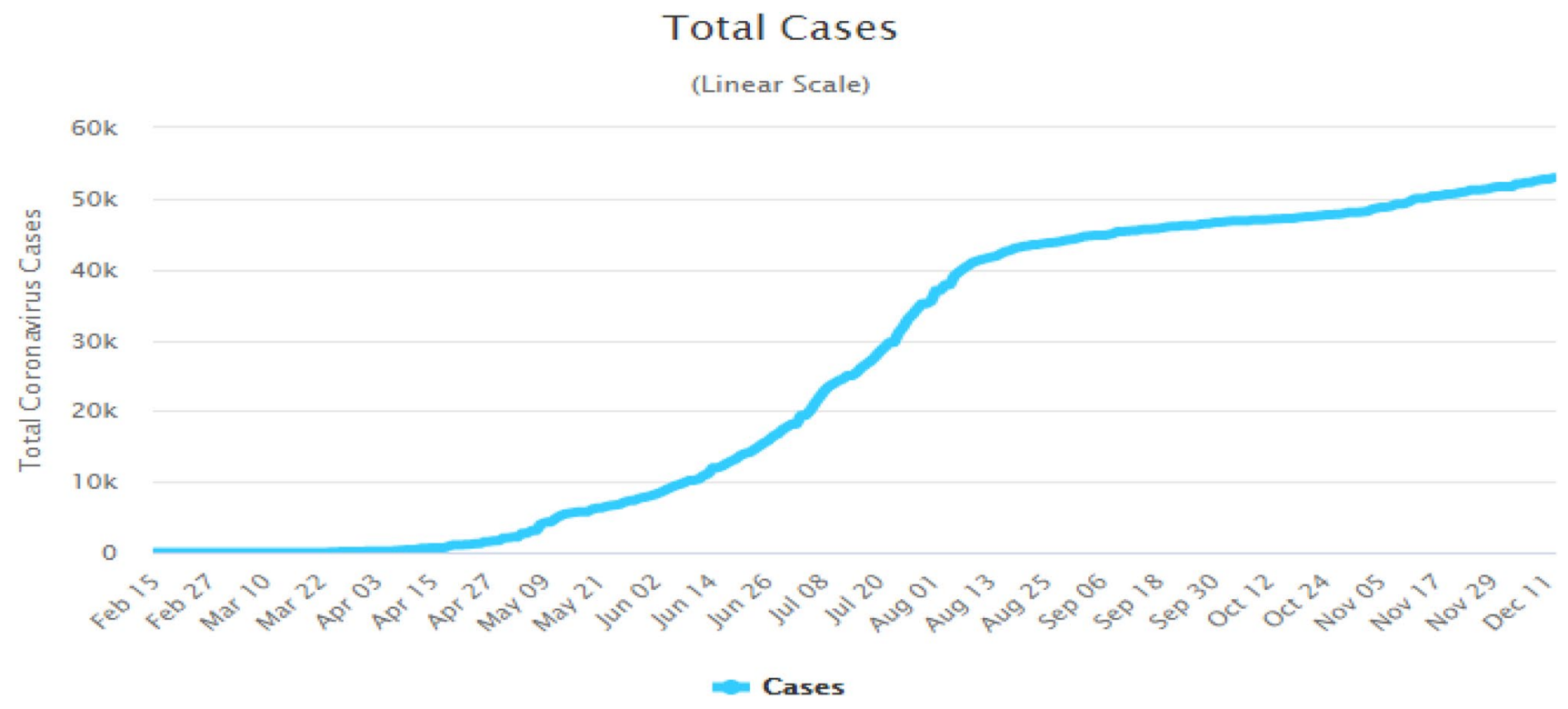

Fig. 1 COVID-19 case progression in Ghana (worldmeters.info) 
level. Tests/exams are paper-based at the basic and secondary level (school and national level), and in most tertiary institutions aside students enrolled in the distance learning program.

\section{Onsite Learning}

The traditional onsite learning which is also conceptualized as face-to-face (F2F) learning [31] is considered to be a teacher-centered approach to instruction which requires passive learning by students [71]. In a teacher-centered onsite mode of instruction, the classroom dynamics is controlled by the teacher through lecturing and giving comments, and the student listens, make notes, and also ask questions. Conversely, a student-centered onsite mode of instruction is referred to as active learning. Students control classroom dynamics by independently constructing questions and asking their teachers for answers or clarification. Jensen et al. [44] associates deep approach to learning to student-centered approach and surface approach to learning to teacher-centered approach. There is a real-time face-to-face instruction in both approaches in a traditional onsite instruction where content delivery is flexible and teachers are able to provide immediate feedback. Onsite instruction occurs in a physical environment between a teacher and a student [80]. Exercises and lectures can be found in onsite learning and that may occur in a class or given as a homework, discussion forums, as individual or team learning [8]. Hence, onsite learning is supported by school buildings such as classrooms, lecture halls, libraries, and laboratories. F2F instruction provides room for relationship building, self-awareness, reflection, in-person activities, and in-class-role plays [79]. There are several studies that stress the importance of maintaining physical connection to campus, peer-to-peer connection, and student-instructor connection [42].

\section{Online Learning}

Online learning is defined as a type of education that occurs synchronously/asynchronously over the internet and does not occur in a traditional onsite classroom [96]. Online learning is grounded in DE [46, 95] and is used as an overlapping concept with e-learning and blended learning [1]. Online education evolved from mere recording of lectures to asynchronous and synchronous mode of delivery [58], and is considered as an important education method today [105]. Asynchronous mode is when students can participate in the online learning process at their own time with different digital tools while synchronous mode is when students participate in live audio/video conferences with immediate feedback [48]. In an online mode of delivery, students are physically distant from their teachers and the interaction between them and teachers is mediated by technology [3].
The first model of online education was initiated by the University of London in the 1800s [71]. Scholars believed that online mode of education is preferable for older students who have financial, familiar, and work-related responsibilities [40]. Online learning makes it possible for prospective students to access quality education through a single internet connection [71]. The flexibility in online learning enables students to determine when and where they learn [38, 45]. The various online learning activities include online discussion forum, personal assignment or group projects, and attending exams in a virtual or physical classroom [91].

\section{Onsite Learning and Online Learning}

Onsite and online learning have similarities aside their differences. In all the two modes of delivery, it is required of learners to attend class, study course material, submit their assignment, and also complete group projects [71]. The authors added that teachers still need to design curriculum, use effective teaching methods, respond to learner's questions, motivate students, and then grade them. Both approaches require a competent teacher and willing students.

The perceptions of students on onsite and online modalities is mixed [13, 18, 51]. According to [51], some learners perceive both modes of instruction as equally effective, and some believe they are of similar quality, and others believe the quality of onsite learning is better than online learning. They added that although students would like to participate in online learning, they consider onsite learning as more preferable. There is more quality student-instructor interaction in onsite classrooms than online learning, although technology can enhance student-instructor interaction in online education [101]. Class discussions among twenty or more students can be confusing in an online class, while in an onsite class, it can be thought-provoking [12]. According to the same authors, it is obvious to detect communication cues in an onsite class but it is almost nonexistent in an online modality. In a normal F2F class, one person speaks at a time while it requires frequent regulation to control who talks at a time in an online class as all students often try to talk at the same time.

Summers et al. 81 examined the difference between online and onsite learning and found that onsite learners were more satisfied than online learners. Tratnik et al. [85] also found that onsite students are significantly satisfied than online students. There is inadequate feedback in online learning and online learners are more likely to drop out than onsite learners [10]. Bergeler and Read [13] mentioned that online undergraduate students perceived online learning as inferior to onsite learning, and onsite learning students enrolled in a linguistic course performed better than their online counterparts. Ferguson and Tryjankowski [30] found that students in an onsite course scored significantly higher than onsite 
learners in a master's level course. There are also numerous studies that have found no meaningful difference between onsite and online learning in terms of student success [101]. Chen and Jia [23] in their study found that there was no significant difference between onsite and online learning in terms of average assignment scores, learning experiences, quality and usability of technology, design of learning assessment, and instructional content. In another study, no significant difference was found on student performance between onsite and online learners in terms of gender and class rank [71]. Smith et al. [77] found that although learners perceived both onsite and online education had gains in their levels of learning, learners perceived online instructional modality to be efficient than onsite instruction. Soffer and Nachmias [78] concludes that there is no clear understanding on the effectiveness of onsite and online learning in terms of measuring the effectiveness of learning outcomes. There are some nations and educational institutions who perceive attaining a degree through online learning as inferior to onsite learning [4, 58].

\section{Online and Onsite Learning During the Pandemic Era}

Online instruction in most African institutions were done through the aid of television, radio, SMS services, e-learning and web-based platforms $[11,83]$. However, the digital divide and limited ICT resources negatively affected the progress of the online learning in many institutions [1, 2]. For example, some institutions in Nigeria experienced problems with the supply of ICT hardware [68] while in Kenya, there was lack of digital tools such as mobile phones [66]. Some of the higher education institutions received limited funding to ensure the effective functioning of the online platform [62]. Some of the students who experienced the online learning also lamented on challenges associated with internet access. In Ethiopia, it was observed that the high cost of internet bundle served as a barrier to students accessing the e-learning platform [59]. In the case of Ghana, aside from limited ICT resources, resistance to the online modality by faculty members, and lack of social interactions, students also complained of lack of electric power supply [1]. The unique challenges of Ghana and other peer countries motivated the government of Ghana to resume onsite learning.

Presently, there are limited literature on students onsite learning experience after the COVID-19 crisis. Nonetheless, educationists in some countries have put plans in place to resume F2F instruction. For example, in the US, the Educations Resource Strategies (ERS) for American education has developed a "COVID-19 comeback model" to aid schools in the resumption of onsite delivery [29]. Although it is originally developed for a school-based context, the universal nature of its guiding principles makes it relevant for higher education institutions as well. The model advocates for leaders to accelerate the learning of students to make up for the learning loss due to the COVID-19 crisis. Additionally, leaders are to ensure students are able to successfully reconnect to school and must increase the emotional and social support for students. Leaders are to set up measures to respond to sanitation and physical distancing requirements. There should be a provision for teachers and students who do not feel secure attending school or have contracted the SARSCov-2. Because of the varying contexts of different universities, the model specifically serves as a guideline for educators and school leaders to create concrete contextual models for school reopening. Firstly, leaders must work with families, educators and other significant people to establish guiding principles. These principles will inform how students and educators will return to school. Secondly, by engaging with families, educators, and community partners, leaders are able to identify the significant social-emotional and academic needs of students. Thirdly, leaders should act proactively to determine and plan for the constraints associated with factors such as physical distancing, class size, transportation, entry and exit of students. Moreover, considering the needs for specific group of students and grade levels, leaders should consider prioritizing and merging alternative models. Finally, leaders should decide on designing schedules and staffing models such as how teachers are assigned to classes, assigning leading roles, appointing teaching teams, and usage of teacher and student time (Fig. 2).

Country school closures and reopenings (data as of September $25^{\text {th }}$ )

\begin{tabular}{|l|c|c|c|c|c|c|c|}
\hline & Africa & EAP & ECA & $\begin{array}{c}\text { LAC and } \\
\text { America }\end{array}$ & MENA & SAR & Total \\
\hline Closed or partly closed & 26 & 10 & 4 & 39 & 19 & 6 & $\mathbf{1 0 4}$ \\
\hline $\begin{array}{l}\text { Open or Open with } \\
\text { limitations }\end{array}$ & 22 & 15 & 46 & 4 & 2 & 2 & $\mathbf{9 1}$ \\
\hline
\end{tabular}

Fig. 2 Country school closures and reopenings (data as of September 25th). Source: World Bank Education Team COVID-19 tracking database and a map; World Bank (2020) 


\section{Methods}

The study employs a qualitative approach to investigate school preparedness towards onsite learning and current strategies being utilized to resume a permanent onsite learning in Ghana. The target population was all students in the tertiary institutions in Ghana. Data was collected using randomly selected tertiary students across three universities in Ghana who temporarily resumed onsite studies after the school closures. A letter of invitation stating the purpose and potential benefits of the study was sent to the randomly selected participants to seek their consent to participate in the study. Twenty students $($ Male $=12$, Female $=8$ ) were recruited from different fields of study across different levels. In Ghana, tertiary education is four years, ranging from level 100 to level 400. Detailed demographic characteristics of the respondents are presented in Table 1.

An interview guide was developed by the researcher after thorough review of extant literature. The interview guide had open-ended questions to enable the researcher to probe into the respondents' views for a deeper insight on the subject matter. Initially, grammatical errors in the interview guide were corrected after proofreading by a colleague. The interview was further assessed by another researcher for screening and validity purposes.

All interviews were conducted in English using the WhatsApp platform. The duration of the interview was between

Table 1 Demographic characteristics of participants

\begin{tabular}{llll}
\hline Participants (P) & Gender & Program & Level \\
\hline P1 & Male & BSc. Actuarial Science & 300 \\
P2 & Male & BSc. Biomedical Engineering & 300 \\
P3 & Male & BSc. Computer Engineering & 100 \\
P4 & Female & B.Ed. Arts & 300 \\
P5 & Male & BSc. Planning and Sustainability & 400 \\
P6 & Female & BSc. Biological Sciences & 200 \\
P7 & Male & BSc. Computer Science & 100 \\
P8 & Female & BA. Public Relations & 100 \\
P9 & Male & B.Ed. Arts & 300 \\
P10 & Female & B.A. Anthropology & 100 \\
P11 & Male & BSc. Physics & 200 \\
P12 & Female & BSc. Nursing & 400 \\
P13 & Male & BSc. Computer Science & 200 \\
P14 & Female & BSc. Nursing & 400 \\
P15 & Male & BSc. Information Technology & 300 \\
P16 & Female & BSc. Nursing & 300 \\
P17 & Male & BSc. Computer Science & 100 \\
P18 & Male & B.Ed. Arts & 300 \\
P19 & Male & BSc. Nursing & 200 \\
P20 & Male & BSc. Mathematics & 400 \\
\hline & & &
\end{tabular}

10 and 15 min for each participant. The focus of the interview was on students' assessment of school preparedness after temporal resumption of studies. The researcher transcribed the interviews verbatim into Microsoft Word Office tool. Concurrently, the interviews were replayed to check for accuracy of the transcription. Pseudonyms were ascribed to every participant to ensure confidentiality.

As of November 2020, online instruction has halted in most institutions in Ghana. Also, online content is not available for basic school students, with second-year JHS and SHS students partially resuming school since October 5, 2020. The study contributes to the discussion of the impact of COVID-19 on education and identifies strategic approaches to resume F2F learning based on secondary data (data were already available on online journal databases and reports).

\section{Results}

Thematic analysis using yielded the following themes; school safety protocols, digital technologies, psychological support, parent-teacher collaboration, class size, course completion (Table 2). Generally, there are mixed experiences of students in terms of their assessment of the schools' preparedness for onsite learning. Some of the students applauded their schools' response to the COVID-19 since school was temporarily resumed for the first batch of students while some also weighed in on unique challenges which they perceived can be a threat to a successful completion of the semester. Based on the emerged themes and sub-themes from analyzing the data collected, ten strategic approaches to onsite learning advocated by experts and researchers in education were suggested. The researcher assumes these methods can lead to a permanent and successful onsite learning while at the same time ensuring the

Table 2 Qualitative themes (categories) and sub-themes (sub-categories) of interview guide responses

\begin{tabular}{ll}
\hline Themes & Sub-themes \\
\hline School safety protocols & $\begin{array}{l}\text { Provision of PPEs } \\
\text { COVID-19 education } \\
\text { Mobile learning } \\
\text { Onigital technologies }\end{array}$ \\
Psychological support & $\begin{array}{l}\text { Student-student and stu- } \\
\text { dent-teacher relationship }\end{array}$ \\
& Counselling services \\
Parent-teacher collaboration & Health safety \\
& Academic outcomes \\
Class size & Social distancing \\
& Class participation \\
Course completion & Course curricula and content \\
\hline
\end{tabular}


health needs of students are cared for. Presently, there have been calls by the teacher association in Ghana (GNAT) to halt the temporal resumption of onsite learning in universities because of the second wave of the virus [35]. The results of the analysis are discussed below.

\section{School Safety Protocols}

Almost all the students interviewed revealed that their universities have put in place concrete plans to ensure their health security is assured. However, they also expressed concern on some issues (such as the provision of PPEs) that need to be addressed to ensure their maximum safety if the onsite learning would persist for a long time.

\section{Provision of PPEs}

A few number of the students indicated that initially, they were provided with some safety PPEs such as nose masks and sanitizers upon arrival at the university campus. Majority of the students revealed that their schools did not provide them with PPEs but only apparatus for handwashing. Hence, there is additional cost on them in the purchase of nose masks and hand sanitizers.

"Well, our school has not provided any of those. But they did provide us with soap and water for washing our hands." [P8].

"In no way has my school helped with the provision of PPEs, each student is required to provide for him/ herself" [P2].

\section{COVID-19 Education}

According to the respondents, a lot of emphasis is laid routinely on preventive techniques regarding the COVID-19 infection. Their schools gave them health talks during orientation and assembly gatherings.

"The school management has consistently been disseminating information about COVID-19 on notice boards and in our online platforms. The management of the school has also created security checkpoints to ensure every student has been checked with thermometer-guns and also ensure that students wash their hands, wear their nose masks, and also sanitize before entering lecture halls. The SRC (Students Representative Council) is also doing well by releasing communiques to create awareness about COVID-19" [P5].

\section{Digital Technologies}

Prior to the temporal resumption of schools, almost all the universities in Ghana adopted online learning to instruct students. Universities therefore used a blend of the online learning and onsite instruction when necessary.

\section{Mobile Learning}

Most of the interviewees responded that their handheld mobile devices aid them to access digital content uploaded by their instructors. One way universities helped students to engage in digital learning was the provision of bundle incentives. However, neither of the universities provided students with these gadgets. Students had to acquire their own ICT tools/mobile gadgets to engage in the digital learning process. There were few of the students who had problems with internet connectivity for the mobile learning.

"Not really. We were not provided with digital learning devices. However, the SRC did a wonderful job by providing students with SIM Cards which is helping students with their online studies, and have also increased data bundle from 2 GB of data to 5 GB" [P5].

"There are passwords on our WIFI and the network connectivity here is so bad. Hence, we go to class always" [P4].

\section{Online Platform}

Because there are problems accessing internet at a high bandwidth in most areas of the country, some of the students lamented on their inability to access the online platform on time. Some of the students also reported that there are issues with the online platform occasionally which hinders successful learning outcome.

"Sometimes you'll be uploading your assignment and the online platform 'jams', so you are unable to complete the upload on time. It can be frustrating and can make you anxious about your score in that course" [P20].

"Hmmm. Actually the network in school is poor due to enormous students making research and other meetings making the online learning very difficult".

\section{Psychological Support}

Students indicated there were mentally sound to pursue their academic goals because of the good interaction and bond with their peers and lecturers. Also, some of the universities were apt to provide psychological health services to students. Nonetheless, some students opined they did not experience psychological support in their schools. 


\section{Student-Student and Student-Teacher Relationships}

Majority of the participants indicated that there is a warm affection between them, their peers, and teachers which makes them feel secured and at home.

"Oh yes! We've managed to familiarize ourselves with one another. Most of the lecturers are cool and easygoing" [P6].

\section{Counselling Services}

Some of the students praised their universities for assuring them of counselling services while some sect of the students reported that they did not receive any official message from school authorities relating to psychological counselling.

"The school has a counselling center in each college for any issue facing student, not particularly on COVID-19. If you go for counselling, your problems would be addressed" [P1].

\section{Parent-Teacher Collaboration}

A high amount of the students expressed that they did not experience a collaboration or discussion between their parents and teachers prior to and on resumption regarding their health safety and academic outcomes.

\section{Health Safety}

Aside the COVID-19 education and the provision of some PPEs, none of the students revealed that instructors/school leaders have been in touch with their parents/caregivers concerning their health.

"The school has no relationship with my parents concerning my safety and academic progress" [P16].

\section{Academic Outcomes}

As mentioned earlier, there seems to be no cooperation between the school and parents in ensuring that amidst the pandemic, students' academics are still not affected.

"Not at all. There is lack of communication between students' guardians and the school. There is poor interaction" [P2].

\section{Class Size}

The multi-track approach (double-track system) adopted by the universities seem to have aided in preventing overcrowding at the lecture halls. Also, the combination of online and onsite learning has helped in reducing class size. According to the students, their current class sizes are okay for their smooth studies.

\section{Social Distancing}

Although the online approach to instruction is adopted to reduce class size, it is not prevalent in all departments at the universities.

"Some colleges use the virtual platforms in their day to day activities. Thus, helping them in their socialdistancing protocol. Other colleges are yet to fuse the virtual platform in the curriculum" [P1].

\section{Class Participation}

The reduced class sizes has enhanced effective student class engagement.

"The space for study is quite manageable. We are all able to participate well in what is being taught" [P12].

\section{Course Completion}

\section{Course Curricula and Content}

In terms of the successful completion of course content, students had differing views. Those at the level 100 felt they would be able to complete their course content as compared to their seniors. Also, because self-learning/regulation is common in most universities, some of the students revealed that instructors would not go back to the previous semester in case they are unable to complete the current semesters' course. Students felt the curriculum is okay for their studies.

"We would not be able to cover most of the course contents. As we all know, we are not in normal times. The pandemic has really affected everything including our academics, we would not be able to complete most courses" [P5].

"I'm a level 100 student and we've covered much so far. So I think we will be able to cover everything by the end of the semester" [P8].

\section{Strategies for Onsite Learning Post SARS-Cov-2}

During the interview phase, the concerns raised by students served as a springboard for identifying strategic approaches to onsite resumption as advocated by researchers and other relevant bodies. Drawing from extant literature, ten (10) current strategic approaches employed for onsite instruction are presented in separate paragraphs below. The summary of the ten approaches is presented in a tabular form at the end of the section (Table 3 ). 
Table 3 Summary of the 10 Strategies for Onsite Learning Post SARS-Cov-2

\begin{tabular}{|c|c|}
\hline Strategy & Explanation \\
\hline School readiness & $\begin{array}{l}\text { Having a resumption plan, education of staff and students, revision of plan, communication with relevant govern- } \\
\text { ment agencies, stakeholders in education, and health experts }\end{array}$ \\
\hline Safety PPEs & $\begin{array}{l}\text { Provision of safety PPEs such as masks, respirators, face shields, gloves to staff and students by local production } \\
\text { and/or liaising with donor bodies }\end{array}$ \\
\hline Mobile technologies & $\begin{array}{l}\text { Adopting cost-effective handheld mobile devices for "m-learning" during and after class hours for effective com- } \\
\text { munication and gamification }\end{array}$ \\
\hline Blended learning & $\begin{array}{l}\text { Geographically distant students can access e-learning platforms from home to reduce class size and maintain } \\
\text { social-distancing norms }\end{array}$ \\
\hline Psychological counselling & $\begin{array}{l}\text { Provision of mental health hotlines and psychological handbook for students. Establishing a guidance and coun- } \\
\text { selling unit to render psychological support to students }\end{array}$ \\
\hline Building strong relationships & $\begin{array}{l}\text { Redesign the school climate and culture in a manner that is conducive for learning and enhance collaboration } \\
\text { among peers and tutors }\end{array}$ \\
\hline Parent-Teacher collaboration & $\begin{array}{l}\text { Ensuring teachers work closely with parents of students engaged in home education and giving academic pro- } \\
\text { gress report to parents of students engaged in the onsite instruction }\end{array}$ \\
\hline Leverage adequate funding & Partnering with NGOs and donor bodies to fund school operations such as the provisions of PPEs \\
\hline Reduce class size & $\begin{array}{l}\text { Splitting classes to prevent overcrowding through blended learning, adoption of a multi-year track system } \\
\text { (double-track system), and employing more qualified teachers }\end{array}$ \\
\hline Curricula & $\begin{array}{l}\text { Orienting students on classroom curriculum and assessments and giving varied assignments which are all tailored } \\
\text { to students' interest. Also, directing students to open access educational sites }\end{array}$ \\
\hline
\end{tabular}

Prior to school resumption, assessment of school readiness should be performed. UNESCO [88] declared that regardless of a country's capacity, to ensure the provision of appropriate and continued access to education in the time of crises and closure of schools, all education system must put plans in place for school reopening when the time comes. Preparedness to resume normal operations in the wake of the COVID-19 has become difficult to operationalize for many organizations [63]. The authors added that for an institution such as schools to resume operations after the closure, there should be a prior plan in place, education, drilling, and a revision of the plan. Also, there should be communication and exchange of relevant information between public, partners, and stakeholders to help them make concrete decisions that align with public health and promote safety especially in the context of school resumption. The CDC [20] also calls for schools to collaborate with local and state health officials for possible resumption. The report mentioned that schools have to implement methods that slow the spread of the SARS-Cov-2. Decision to reopen schools should be based on available data on the extent of community transmission and the ability of schools to protect their students, teachers, administrators, and other staffs. Schools can set up a "Return to School Committee" which consists of parents, health professionals, staffs, and administrators on appropriate measures to put in place to ensure safe reopening of schools [103]. Additional set, protocols, and infrastructure up may be required for resuming physical school operations to observe sanitation and social-distancing guidelines [50]. If there a real learning loss as a result of the pandemic, schools should develop a curriculum framework for school reopening that will ensure effective teaching [24]. Lack of school readiness, safety of teachers, challenges of learners with disabilities, and meeting the educational needs of students should be addressed [70]. Lessons can be acquired from other countries on school resumption [104].

Also safety Personal Protective Equipment (PPEs) such as masks, respirators, shoes, face shield, head cover, gown, googles, and gloves play a crucial role in the prevention and control of the SARS-Cov-2 [56]. Educators should work with local and national health officials, and also donor bodies to secure PPEs for students and staffs. In Ghana, the local production of PPEs and homemade hand sanitizers increased the accessibility of these products for protection against the virus [76, 102]. Used PPEs should also be discarded properly to prevent environmental health problems [105].

Mobile technologies can increase student-teacher and student-student communicative interactions, teaching practices, and enhance learning processes [6]. Utilizing mobile technologies in education is termed as "m-learning". The use of mobile technologies such as smartphones and tablets can be incorporated into the teaching and learning than conventional laptops [32]. Laptops and desktop computers can be expensive and mobility might be difficult as compared to some mobile devices that can be surf the internet and create new content [1]. Students can remain distant and access content and learn new information without necessarily visiting computer laboratories at school. Also, mobile technologies can be used after school hours to stay in touch with teachers and peers, and can also be used for group project works. The Ministry of Education and School institutions can adopt mobile technology as a blended approach to onsite learning 
instead of costly laptops. Through mobile technologies, a microblog can be initiated during class hours and this can help students who are afraid to ask questions or give oral feedback to teachers [72]. "Gamification" of learning process can also be implemented through mobile technologies. Mobile technologies can by allowing richer forms of communication can also generate a feeling of social presence to prevent the feelings of solitude when completing assignments [28].

A blended mode of instruction can be adopted by universities. Blending learning is an integration of online and onsite learning [1]. A blended approach to learning can improve higher education in a post-pandemic situation [19]. To mitigate the challenge of geographical distance, those who are far from school premises and are capable of joining an online class can continue their education with blended learning. The blended learning can also help in reducing large classes in the effort to ensure social-distancing norms. The blended approach promotes flexibility in learning and also building personal learning networks. Xue et al. [99] opined that both onsite and blended online learning would be widely implemented in a post-pandemic era.

Furthermore, universities should provide mental health services to students and other faculty members in the school. The closure of schools led to psychological and medical damage on students, parents, and teachers [25]. Schools should consider the impact of the COVID-19 pandemic on the mental health, behavioral, and socio-emotional wellbeing of students [20]. There is anxiety among parents and students about when life will return to "normal" [27]. Teachers and counsellors of educational institutions should make it a priority on how to provide reassurance to parents and students. In order for learning to occur, the psychological safety of students should be guaranteed [75]. In Wuhan, China, special psychological and psychiatry services were implemented during the COVID-19 outbreak to provide mental health support across the country including students [90]. A handbook for psychological protection of students and parents were provided, and also mental health hotlines were made available for students and others who needed support. It is essential to closely monitor the psychological status of students, provide psychological intervention, and improve their psychological help-seeking behavior [52].

Moreover, good student-student and student-teacher relationships should be fostered in the universities. Schools should be redesigned in a manner that builds stronger relationships among staffs and students [75]. Quality relationship between teachers and students can be forged by teachers communicating positive expectations to students, ensuring equity in the classroom by giving every student an opportunity to respond to questions/ express themselves, giving student adequate time to think through questions, giving students clues to help them answer questions, developing classroom pride, correcting students constructively, demonstrating caring, and reducing frustration and stress [17]. Students can benefit from the nurturing relationships with their teachers. Teachers can form teaching teams or ensure teacher collaboration to adopt the right approaches to instruction. A positive school climate/culture is needed most in this time of COVID-19.

A large body of research have shown that parent-teacher collaboration contributes to overall school effectiveness [39, 47, 82]. Parent and teacher collaboration is vital for the academic and personal growth of students [64]. Effective school-parent-teacher collaboration reduces absenteeism and dropout rates. The first teacher of a student is the parent [41]. Developing a Parent-Teacher Association with a clear direction on how to assist students to learn at home in this COVID-19 pandemic can help in the education recovery process. Teachers can make a simple phone call to their students' parents or text them to help continue education at home. Sutarto and Sari [82] added that parent and teachers are considered as partners who can work together to ensure the success of learning. Inadequate cooperation between parent and teachers can affect student academic outcomes. Home visit to student's homes could be an effective strategy to develop their interest in education and ensure effective learning after school hours in this COVID-19 pandemic era [75]. The reopening of schools would also mean that parents would require frequent monitoring of the school environment [25]. School leaders should collaborate with parents/caregivers on how to promote safety and ensure a conducive environment for students. The parent-teacher collaboration can reduce the academic stress of students [69].

School leaders can partner with stakeholders in education/community, international donors and NGOs to gain funds for school operations [75]. Since the COVID-19 had a negative economic impact, schools in rural areas or not affluent may find it difficult to ensure effective functioning. Special arrangements for maintaining social distancing and sanitation norms can come at a huge cost which can be defrayed by partnering with governments and other bodies willing to invest in education. Policymakers should implement policies that provide adequate funds for schools for effective operation.

Onsite learning will require a reduction in the number of students who teachers interact with F2F [75]. Schools with large classes should consider splitting the classes to prevent overcrowding and ensure the social-distancing norms. Reducing large classes to make room for adequate space can slow the spread of the virus. In such instance, extra-teachers may be needed. School who may not have the adequate capacity/facilities for splitting classes can run on shifts (students come in turns from morning to afternoon) or adopts a double-track approach (first group of students come 
to school for the academic year and later replaced during vacation by another sect of students who stayed at home).

Whether teachers would use a national curricula or use their discretion to choose program content for their students, teachers should not only orient students on classroom curriculum and examinations/assessments, but also give them varied homework and examinations [27]. Educators should also formulate an appropriate plan to recover course content that could not be completed as a result of the pandemic. According to [27], there is also abundance of high-quality educational materials which are open access as a result of the pandemic, which teachers can draw from to instruct students. A suggested website is the OpenLearn Website which contains over 1000 courses for students at the school and tertiary level. School leaders should solicit ideas from curriculum designers and experts before implementing a new curriculum to promote students' interest.

\section{Theoretical and Practical Implications}

Theoretically, the papers add knowledge to the myriad of studies that discusses the impact of the COVID-19 crisis on the status quo of education. The conceptualization of online learning according to diverse scholars has been briefly discussed in the study. A clear distinction was made between online and onsite learning while factoring in their advantages and disadvantages. Based on the extant review of literature on these two modalities of instruction, there are differing views on the effectiveness, students' preference, and teachers' attitude towards online and onsite learning. More research that applies rigorous and sophisticated methods are needed for accurate conceptualization of these two modes of instruction. Although online learning is used interchangeably with similar concepts such as e-learning, flipped learning, virtual classes, and distance education [1], the concepts have differences that need to be accurately explored. Practically, the COVID-19 is on the rise as most countries are experiencing a second wave and thinking of re-closing schools [35]. It behoves on school administrators and policymakers in education to address the frugal needs of school, in the context of this paper, higher education institutions. Because the previous experience of students regarding the emergent online learning in Ghana was not the best $[1,9]$, school leaders have to address the challenges of the online instruction and strategically plan for a successful resumption of onsite instruction. First and foremost, as advocated by researchers reviewed earlier and in the COVID-19 comeback model, the government and educators should partner with relevant stakeholders such as parents and health officials before arriving at a decision to resume in school. In Ghana, there seems to be conflicting views of the Ghana Medical Association and government's decision to resume temporarily school [34]. Also, parents' opinion was not sought and the GNAT have supported the re-closure of schools which has become a public chorus [35]. Secondly, school leaders should liaise with the government and donor bodies in acquiring the safety PPEs for protection and handwashing machines (or veronica buckets which are less expensive and effective) to foster frequent handwashing in the school environment. Thirdly, universities with no "guidance and counselling unit" or "psychological support" department should establish them to provide psychological health services to students and employees. Since poor psychological health is linked with negative academic outcomes and reduced productivity [43]. To ensure social-distancing norms are maintained, school can use a blend of both online and onsite instruction to reduce class sizes. This will also help teachers to give special attention to individual students and for the students to rapidly engage in the learning process. For example, in Wuhan University in China, multifactorial techniques such as in-person psychological counselling and the rapid use of online learning were employed for a successful resumption of activities after the COVID19 pandemic [73]. Health centers in the university setting should rapidly check student and faculty staffs' temperatures and provide adequate healthcare. The curricula developed should be tailored to students' needs and interest to engage them and also complete semester courses on time. Proper assessment techniques can be employed to identify any hurdle to course completion and challenges with instruction delivery. Overall, school resumption needs to be carefully planned using the suggested points as guidelines to ensure progressive education.

\section{Conclusion}

In recent weeks, there has been a spike in the number of COVID-19 cases in Ghana, raising concerns about a second wave [49, 84]. With the Ghanaian government's decision to resume onsite instruction across all levels of education in early 2021, there is a need to discuss strategic approaches to resume onsite learning. The paper argued that the failure of the emergent online education in the country forced the hand of the government to resume onsite learning temporarily, with universities adopting a multi-track approach (doubletrack system) to accommodate students because of limited physical space $[1,37]$. However, school leaders and parents were not consulted before the decision to resume schools. The resumption amidst the fast rising cases of COVID-19 has been met with resistance from parents, teachers, and health professionals $[34,35]$. According to teachers, the preparedness plan of schools to resume onsite education is not adequate because schools lack funds, facilities, and PPEs. Although Ghana is used as a case study, the strategies suggested is applicable to all countries across the globe 
who hopes to resume F2F instruction. Specifically, school readiness/preparedness, acquisition of PPEs, mobile technologies, blended learning, provision psychological counselling services, building stronger relationships at school, school parent-teacher collaboration, leveraging adequate funding, reducing class size, and redesigning a curriculum with varied content that promotes students' interest were found to be integral for resumption of onsite instruction. Although the COVID-19 has had a devastating effect on the education sector, it is a stimulus for educators across the globe to rethink how to improve teaching and learning [21], especially in the context of developing countries were onsite instruction is imminent and inevitable because of the failure of online education. Policymakers and stakeholders in education should prepare fully for both online and onsite learning activities. Although the paper presents strategic approaches to the resumption of onsite learning, the list is not exhaustive. Future researchers should explore various ways how onsite learning can be used to mitigate the loss in education as a result of the COVID-19 pandemic.

\section{Appendix (Interview Guide)}

\section{Section A}

\section{Background Information}

a. What is your gender?

b. What is your study program?

c. What is your level at school?

\section{Section B}

1. How has your school helped you with the provision of PPEs such as nose masks, gloves and sanitizers?

2. Describe to me how your school has helped in educating you on the COVID-19 and its safety protocols?

3. How do you maintain the health protocols such as social-distancing norms and frequent handwashing in your school?

4. How well do you use digital technologies in your school?

Probe:Can you briefly tell me about your experience with the online learning after school closure?

5. Did your school provide you with electronic gadgets to study online?

6. Can you access the online platform with your mobile devices such as smartphones and tablets and use it for uploading assignment and completing exercises?

7. How has the school dealt with your anxiety about contracting the virus?
Probe: Describe your experiences with how the school has provided psychological counselling to students with psychological health issues in light of the COVID-19.

8. Tell me about student-student and student-teacher relationships in your school?

Probe: Do you think your teacher care about your needs?

9. Can you tell me about how the school has worked with your parents to ensure your safety and your academic progress?

10. Do you get worried about your class size? Would you say you have enough space to study comfortably?

Probe: How has your class size affected your academics?

11. Do you think you'll be able to complete the course content that was not covered in the previous semester $\&$ this current semester? Why and why not?

\section{Declarations}

Conflict of Interest The authors declare that they have no conflict of interests.

\section{References}

1. Adarkwah MA. "I'm not against online teaching, but what about us?": ICT in Ghana post Covid-19. Educ Inf Technol. 2020. https://doi.org/10.1007/s10639-020-10331-z.

2. Adnan M, Anwar K. Online learning amid the COVID-19 pandemic: students'. J Pedagogical Sociol Psychol. 2020;2(1):45-51. https://doi.org/10.33902/JPSP.2020261309.

3. Aguilera-Hermida PA. College students' use and acceptance of emergency online learning due to COVID-19. Int J Educ Res Open. 2020. https://doi.org/10.1016/j.ijedro.2020.100011.

4. Allen EI, Seaman J. Online report card: tracking online education in the United States. Babson Survey Research Group; 2016.

5. Almaiah MA, Al-Khasawneh A, Althunibat A. Exploring the critical challenges and factors influencing the E-learning system usage during COVID-19 pandemic. Educ Inf Technol. 2020;25:5261-80. https://doi.org/10.1007/s10639-020-10219-y.

6. Alshehri A, Cumming TM. Mobile Technologies and Knowledge Management in higher education institutions: students and educators' perspectives. World J Educ. 2020;10(1):12-22. https:// doi.org/10.5430/wje.v.

7. Amaglo-Mensah TD. Possible ramifications of Covid-19 on the future of education delivery in Ghana; 2020. https://www.ukfiet. org/2020/possible-ramifications-of-covid-19-on-the-future-ofeducation-delivery-in-ghana/.

8. Anggrawan A, Jihadil QS. Comparative analysis of online e-learning and face to face learning: an experimental study. In: 2018 Third International Conference on Informatics and Computing (ICIC); 2018. IEEE.

9. Anyorigya DA. COVID-19: Halt challenge-ridden online learning in universities - NUGS to Government; 2020. https://citin 
ewsroom.com/2020/04/covid-19-halt-challengeridden-onlinelearning-in-universities-nugs-to-government/.

10. Atchley W, Wingenbach G, Akers C. Comparison of course completion and student performance through online and traditional courses. Int Rev Res Open Dist Learn. 2013;14(4):10416. https://doi.org/10.19173/irrodl.v14i4.1461.

11. Azu OB, Adegboye O, Quadri H. Who gets to learn in a pandemic? Exploring the digital divide in remote learning during the COVID-19 pandemic in Nigeria. Int J Educ Res Open. 2020. https://doi.org/10.1016/j.ijedro.2020.100022.

12. Barnett D, Aagaard L. Online vs face-to-face instruction: similarities, differences, and efficacy. Morehead State University; 2005.

13. Bergeler E, Read MF. Comparing learning outcomes and satisfaction of an online algebra-based physics course with a faceto-face course. J Sci Educ Technol. 2020. https://doi.org/10. 1007/s10956-020-09878-w.

14. Berghout E. COVID and opportunities for information systems management research. Inf Syst Manag. 2020;37(4):357-60. https://doi.org/10.1080/10580530.2020.1820640.

15. Bhagat S, Kim DJ. Higher education amidst COVID-19: challenges and silver lining. Inf Syst Manag. 2020;37(4):366-71. https://doi.org/10.1080/10580530.2020.1824040.

16. Bosumtwi-Sam C, Kabay S. Using data and evidence to inform school reopening in Ghana; 2020. https://www.povertyaction.org/blog/using-data-and-evidence-inform-school-reope ning-ghana.

17. Boynton M, Boynton C. Educator's guide to preventing and solving discipline problems. Alexandria: ASCD; 2005.

18. Brown JL, Park H-S. Longitudinal student research competency: comparing online and traditional face-to-face learning platforms. Adv Soc Work. 2016;17(1):44-58. https://doi.org/ $10.18060 / 20870$.

19. Calderón A, Scanlon D, MacPhail A, Moody B. An integrated blended learning approach for physical education teacher education programmes: teacher educators' and pre-service teachers' experiences. Phys Educ Sport Pedagog. 2020. https://doi. org/10.1080/17408989.2020.1823961.

20. CDC. Operating schools during COVID-19: CDC's considerations. Center for Disease Control and Prevention; 2020.

21. Chatterjee I, Chakraborty P. Use of information communication technology by medical educators amid COVID-19 Pandemic and beyond. J Educ Technol Syst. 2020. https://doi.org/ 10.1177/0047239520966996.

22. Chen J, Wang X, Zhang S, Lin B, Wu X, Wang Y, et al. Characteristics of acute pulmonary embolism in patients with COVID-19 associated pneumonia from the city of Wuhan. Clin Appl Thromb Hemost. 2020;26:1-8. https://doi.org/10.1177/ 1076029620936772.

23. Chen W, Jia J. Comparison of online and onsite students' learning outcomes and experiences in a massively open online course in China. J Educ Technol Dev Exchange. 2016;9(1):6788. https://doi.org/10.18785/jetde.0901.05.

24. Coker D. The canary in the mine: remote learning in the time of COVID-19. J Curric Teaching. 2020;9(3):76-87. https://doi. org/10.5430/jct.v9n3p76.

25. Cooper DM, Guay-Woodford L, Blazar BR, Bowman S, Byington CL, Dome J, et al. Reopening schools safely: the case for collaboration, constructive disruption of pre-coronavirus 2019 expectations, and creative solutions. J Pediatr. 2020. https:// doi.org/10.1016/j.jpeds.2020.05.022.

26. Crawford J, Butler-Henderson K, Rudolph J, Malkawi B, Glowatz M, Burton R, et al. COVID-19: 20 countries' higher education intra-period digital pedagogy responses. J Appl Learn Teach. 2020;3(1):9-28. https://doi.org/10.37074/jalt. 2020.3.1.7.
27. Daniel SJ. Education and the COVID-19 pandemic. Prospects. 2020;49:91-6. https://doi.org/10.1007/s11125-020-09464-3.

28. Dwivedi YK, Hughes DL, Coombs C, Constantiou I, Duan Y, Edwards JS, et al. Impact of COVID-19 pandemic on information management research and practice: transforming education, work and life. Int J Inf Manage. 2020. https://doi.org/10. 1016/j.ijinfomgt.2020.102211.

29. Education Resource Strategies. Decision points for COVID comeback models. Education Resource Strategies; 2020.

30. Ferguson J, Tryjankowski AM. Online versus face-to-face learning: looking at modes of instruction in Master's-level courses. J Furth High Educ. 2009;33(3):219-28. https://doi. org/10.1080/03098770903026149.

31. Fillion G, Limayem M, Laferrière T, Mantha R. Integrating information and communication technologies into higher education: investigating onsite and online students' points of view. Open Learn. 2009;24(3):223-40. https://doi.org/10.1080/ 02680510903201649.

32. France D, Lee R, Maclachlan J, Mcphee SR. Should you be using mobile technologies in teaching? Applying a pedagogical framework. J Geogr Higher Edu. 2020. https://doi.org/10.1080/ 03098265.2020.1773417.

33. Ghana Health Service. 2020. https://www.ghanahealthservice. org/covid19/.

34. GhanaWeba. Close schools now - Ghana Medical Association to govt. 2021. https://www.ghanaweb.com/GhanaHomePage/ NewsArchive/Close-schools-now-Ghana-Medical-Associationto-govt-1174774.

35. GhanaWebb. GNAT supports re-closure of schools. 2021. https://www.ghanaweb.com/GhanaHomePage/NewsArchive/ GNAT-supports-re-closure-of-schools-1157876.

36. Goyal JK, Daipuria P, Jain S. An alternative structure of delivering management education in India. J Educ Technol Syst. 2020. https://doi.org/10.1177/0047239520958612.

37. Gyampoh AO, Ayitey HK, Fosu-Ayarkwah C, Ntow S, Akossah $\mathrm{J}$, Gavor M, Vlachopoulos D. Tutor perception on personal and institutional preparedness for online teaching-learning during the COVID-19 crisis: the case of Ghanaian Colleges of Education. Afr Educ Res J. 2020;8(3):511-8. https://doi.org/10. 30918/AERJ.83.20.088.

38. Henderikx M, Kreijns K, Muñoz JC, Kalz M. Factors influencing the pursuit of personal learning goals in MOOCs. Distance Educ. 2019;40(2):187-204. https://doi.org/10.1080/01587919. 2019.1600364.

39. Hoang A-D. Pandemic and teacher retention: empirical evidence from expat teachers in Southeast Asia during COVID19. Int J Sociol Soc Policy. 2020;40(9/10):1141-66. https:// doi.org/10.1108/IJSSP-07-2020-0269.

40. Hussein E, Daoud S, Alrabaiah H, Badawi R. Exploring undergraduate students' attitudes towards emergency online learning during COVID-19: a case from the UAE. Child Youth Serv Rev. 2020. https://doi.org/10.1016/j.childyouth.2020.105699.

41. Iyengar R. Education as the path to a sustainable recovery from COVID-19. Prospects. 2020;49:77-80. https://doi.org/10.1007/ s11125-020-09488-9.

42. Jaggars SS. Choosing between online and face-to-face courses: community college student voices. Am J Distance Educ. 2014;28(1):27-38. https://doi.org/10.1080/08923647.2014. 867697.

43. Jeffries V, Salzer MS. Mental health symptoms and academic achievement factors. J Am Coll Health. 2020. https://doi.org/ 10.1080/07448481.2020.1865377.

44. Jensen L, Price L, Roxå T. Seeing through the eyes of a teacher: differences in perceptions of HE teaching in face-to-face and digital contexts. Stud High Educ. 2020;45(6):1149-59. https:// doi.org/10.1080/03075079.2019.1688280. 
45. Joosten T, Cusatis R. Online learning readiness. Am J Distance Educ. 2020;34(3):180-93. https://doi.org/10.1080/08923647. 2020.1726167.

46. Joshi O, Chapagain B, Kharel G, Poudyal NC, Murray BD, Mehmood SR. Benefits and challenges of online instruction in agriculture and natural resource education. Interact Learn Environ. 2020. https://doi.org/10.1080/10494820.2020.1725896.

47. Kaden U. COVID-19 school closure-related changes to the professional Life of a K-12 teacher. Educ Sci. 2020;10(6):1-13. https://doi.org/10.3390/educsci10060165.

48. Kim J. Learning and teaching online during Covid-19: Experiences of student teachers in an early childhood education practicum. Int J Early Childhood. 2020;52:145-58. https://doi.org/10. 1007/s13158-020-00272-6.

49. Kokutse F. Ghana suspends parliament amid a surge in COVID19 cases. 2021. https://www.washingtonpost.com/world/africa/ ghana-suspends-parliament-amid-a-surge-in-covid-19-cases/ 2021/02/10/eed791f0-6b8b-11eb-a66e-e27046e9e898_story. html.

50. Kumar R, Mittal P. COVID-19 response toolkit for Indian higher education institutions: institutional resilience for academic planning and continuity. Jindal Globa University; 2020.

51. Landrum B, Bannister J, Garza G, Rhame S. A class of one: students' satisfaction with online learning. J Educ Bus. 2020. https://doi.org/10.1080/08832323.2020.1757592.

52. Liang S-W, Chen R-N, Liu L-L, Li X-G, Chen J-B, Tang S-Y, Zhao J-B. The psychological impact of the COVID-19 Epidemic on Guangdong college students: the difference between seeking and not seeking psychological help. Front Psychol. 2020;11:2231. https://doi.org/10.3389/fpsyg.2020.02231.

53. Lorusso NS, Shumskaya M. Online laboratory exercise on computational biology: phylogenetic analyses and protein modeling based on SARS-CoV-2 data during COVID-19 remote instruction. Biochem Mol Biol. 2020;48(5):526-7. https://doi.org/10. 1002/bmb.21438

54. Lovelace BJ. WHO warns coronavirus vaccine alone won't end pandemic: 'We cannot go back to the way things were'. 2020. https://www.cnbc.com/2020/08/21/who-warns-a-coronavirusvaccine-alone-will-not-end-pandemic.html.

55. Mahase E. Covid-19: Pfizer and BioNTech submit vaccine for US authorisation. BMJ. 2020;371:m4552. https://doi.org/10.1136/ bmj.m4552.

56. Mahmood SU, Crimbly F, Khan S, Choudry E, Mehwish S. Strategies for rational use of personal protective equipment (PPE) among healthcare providers during the COVID-19 crisis. Cureus. 2020;12(5):1-10. https://doi.org/10.7759/cureus.8248.

57. Major C. Innovations in teaching and learning during a time of crisis. Innov High Educ. 2020;45:265-6. https://doi.org/10.1007/ s10755-020-09514-w.

58. Malan M. Engaging students in a fully online accounting degree: an action research study. Acc Educ. 2020;29(4):321-39. https:// doi.org/10.1080/09639284.2020.1787855.

59. Mengistie TA. Impact of covid-19 on the Ethiopian education system. Sci Insigt Edu Front. 2020;6(1):569-78. https://doi.org/ 10.15354/sief.20.or011.

60. Ministry of Education. COVID-19 coordinated education response plan for Ghana. Ministry of Education; 2020.

61. Mohammed WF. What COVID-19 reveals about educational inequality in Ghana. 2020. https://www.aljazeera.com/featu res/2020/4/7/what-covid-19-reveals-about-educational-inequ ality-in-ghana.

62. Muftahu M. Higher education and Covid-19 pandemic: matters arising and the challenges of sustaining academic programs in developing African universities. Int J Educ Res Rev. 2020;5(4):417-23. https://doi.org/10.24331/ijere.776470.
63. Mwende R, Mramba C, Mutonga D, Nchogu R, Ogendo M, Ngechu D, et al. College conversion into Covid-19 quarantine center: readiness of students to go back to college. Afr J Educ Pract. 2020;6(6):64-74.

64. Myende PE, Nhlumayo BS. Enhancing parent-teacher collaboration in rural schools: parents' voices and implications for schools. Int J Leadersh Educ. 2020. https://doi.org/10.1080/13603124. 2020.1731764.

65. MyJoyOnline. Academic year for pre-tertiary students to resume in 2021- Akufo Addo. 2020. https://www.myjoyonline.com/news/ national/new-academic-year-to-resume-in-2021-akufo-addo/.

66. Ngari SM, Ndung'u SW. Disaster management preparedness in the education sector in Kenya-a case of the COVID-19 pandemic. Editon Cons J Educ Manag Leadership. 2020;1(1):86-96. https://doi.org/10.51317/ecjeml.v1i1.192.

67. Nguyen MH, Gruber J, Fuchs J, Marler W, Hunsaker A, Hargittai E. Changes in digital communication during the COVID-19 global pandemic: implications for digital inequality and future research. Social Media + Society. 2020. https://doi.org/10.1177/ 2056305120948255.

68. Oyediran WO, Omoare AM, Owoyemi MA, Adejobi AO, Fasasi RB. Prospects and limitations of e-learning application in private tertiary institutions amidst COVID-19 lockdown in Nigeria. Heliyon. 2020. https://doi.org/10.1016/j.heliyon.2020.e05457.

69. Pajarianto H, Kadir A, Galugu N, Sari P, Februanti S. Study from home in the middle of the COVID-19 pandemic: analysis of religiosity, teacher, and parents support against academic stress. Tamkang J Math. 2020;12(2):1791-807.

70. Parker R, Morris K, Hofmeyr J. Education, inequality, and innovation in the time of COVID-19. Johannesburg: JET Education Services; 2020.

71. Paul J, Jefferson F. A comparative analysis of student performance in an online vs. face-to-face environmental science course from 2009 to 2016. Front Comput Sci. 2019;1(7):1-9. https://doi. org/10.3389/fcomp.2019.00007.

72. Raelovich SA, Mikhlievich YR, Norbutaevich KF, Mamasolievich JD, Karimberdievich AF, Suyunbaevich KU. Some didactic opportunities of application of mobile technologies for improvement in the educational process. J Crit Rev. 2020;7(11):348-52. https://doi.org/10.31838/jcr.07.11.60.

73. Sa Y, Lin W-S, Morton D, Huang C. Coronavirus disease 2019 (COVID-19): experiences and protocols from the department of prosthodontics at the Wuhan University. J Prosthet Dent. 2020. https://doi.org/10.1016/j.prosdent.2020.06.004.

74. Sahoo P, Ashwani. COVID-19 and Indian economy: impact on growth, manufacturing, trade and MSME sector. Glob Bus Rev. 2020;21(5):1159-83. https://doi.org/10.1177/0972150920 945687.

75. Schachner A, Darling-Hammond L, Martinez M. Restarting and reinventing school: learning in the time of COVID and beyond. Learning Policy Institute; 2020.

76. Sibiri H, Prah D, Zankawah SM. Containing the impact of COVID-19: review of Ghana's response approach. Health Policy Technol. 2020. https://doi.org/10.1016/j.hlpt.2020.10.015.

77. Smith RL, Flamez B, Vela JC, Schomaker SA, Fernandez MA, Armstrong SN. An exploratory investigation of levels of learning and learning efficiency between online and face-to-face instruction. Counsel Outcome Res Eval. 2015;6(1):47-57. https://doi. org/10.1177/2150137815572148.

78. Soffer T, Nachmias R. Effectiveness of learning in online academic courses compared with face-to-face courses in higher education. J Comput Assist Learn. 2018;34(5):534-43. https://doi. org/10.1111/jcal.12258.

79. Stauss K, Koh E, Collie M. Comparing the effectiveness of an online human diversity course to face-to-face instruction. J Soc 
Work Educ. 2018;54(3):492-505. https://doi.org/10.1080/10437 797.2018.1434432.

80. Steinbronn PE, Merideth EM. Perceived utility of methods and instructional strategies used in online and face-to-face teaching environments. Innov High Educ. 2008;32:265-78. https://doi. org/10.1007/s10755-007-9058-4.

81. Summers JJ, Waigand A, Whittaker TA. A comparison of student achievement and satisfaction in an online versus a traditional face-to-face statistics class. Innovative High Educ. 2005;29(3):233-50. https://doi.org/10.1007/s10755-005-1938-x.

82. Sutarto S, Sari DP. Teacher strategies in online learning to increase students' interest in learning during COVID-19 pandemic. Jurnal Konseling dan Pendidikan. 2020;8(3):129-37. https://doi.org/10.29210/147800.

83. Tadesse S, Muluye W. The impact of COVID-19 pandemic on education system in developing countries: a review. Open J Soc Sci. 2020;8:159-70. https://doi.org/10.4236/jss.2020.810011.

84. Tih F. Ghana sees record spike in coronavirus cases. 2020. https://www.aa.com.tr/en/africa/ghana-sees-record-spike-incoronavirus-cases/2036828.

85. Tratnik A, Urh M, Jereb E. Student satisfaction with an online and a face-to-face Business English course in a higher education context. Innov Educ Teach Int. 2019;56(1):36-45. https://doi.org/ 10.1080/14703297.2017.1374875.

86. Turnbull D, Chugh R, Luck J. Learning management systems: an overview. Encyclopedia Educ Inf Technol. 2019. https://doi. org/10.1007/978-3-319-60013-0_248-1.

87. UNESCO. Distance learning solutions. 2020. https://en.unesco. org/covid19/educationresponse/solutions.

88. UNESCO. Prepare for school reopening: IIEP-UNESCO's COVID-19 response briefs. 2020. http://www.iiep.unesco.org/ en/five-steps-support-education-all-time-covid-19.

89. UNICEF (2020) Ghana: COVID-19 situation report- \#5.

90. Wang Y, Zhao X, Feng Q, Liu L, Yao Y, Shi J. Psychological assistance during the coronavirus disease 2019 outbreak in China. J Health Psychol. 2020;25(6):733-7. https://doi.org/10. 1177/1359105320919177.

91. Wei H-C, Chou C. Online learning performance and satisfaction: do perceptions and readiness matter? Distance Educ. 2020. https://doi.org/10.1080/01587919.2020.1724768.

92. WHO. Coronavirus disease (COVID-19) advice for the public. 2020. https://www.who.int/emergencies/diseases/novel-coron avirus-2019/advice-for-public.

93. WHO. Risk communication and community engagement readiness and initial response for novel coronaviruses (nCoV). World Health Organization; 2020.

94. WHO. Statement on the Second Meeting of the International Health Regulations (2005) Emergency Committee Regarding the Outbreak of Novel Coronavirus (2019-nCoV). 2020. https:// www.who.int/news-room/detail/30-01-2020-statement-on-thesecond-meeting-of-the-international-health-regulations-(2005)emergency-committee-regarding-the-outbreak-of-novel-coron avirus-(2019-ncov).
95. Woldeab D, Yawson RM. A systematic meta-analytic review of thinking beyond the comparison of online versus traditional learning. J Bus Educ Scholar Teach. 2020;14(1):1-24.

96. Wong R. When no one can go to school: does online learning meet students' basic learning needs? Interact Learn Environ. 2020. https://doi.org/10.1080/10494820.2020.1789672.

97. World Bank (2020) Education systems' response to COVID-19 brief no. 15. 2020. https://www.worldbank.org/en/topic/educa tion/coronavirus.

98. Wotto M. The future high education distance learning in Canada, the United States, and France: insights from before COVID-19 secondary data analysis. J Educ Technol Syst. 2020;49(2):26281. https://doi.org/10.1177/0047239520940624.

99. Xue E, Li J, Xu L. Online education action for defeating COVID19 in China: an analysis of the system, mechanism and mode. Educ Philos Theory. 2020. https://doi.org/10.1080/00131857. 2020.1821188.

100. Yakubu N. Schools to reopen on January 15 - Akufo-Addo. 2021. https://www.myjoyonline.com/schools-to-reopen-on-janua ry-15-akufo-addo/.

101. Yen S-C, Lo Y, Lee A, Enriquez J. Learning online, offline, and in-between: comparing student academic outcomes and course satisfaction in face-to-face, online, and blended teaching modalities. Educ Inf Technol. 2018;23:2141-53. https://doi.org/10. 1007/s10639-018-9707-5.

102. Yendork JS, James S. COVID-19 in Ghana: changes and the way forward. J Comp Fam Stud. 2020;51(3-4):369-84. https://doi. org/10.3138/jcfs.51.3-4.012.

103. Young M. Chatfield school COVID-19 preparedness and response plan. Saginaw Valley State University; 2020.

104. Zafitsara J, Velo NM. Madagascar's responses to the COVID-19 outbreak: educational perspectives from March to June 2020. Electr Res J Soc Sci Human. 2020;2(3):116-37.

105. Zand AD, Heir AV. Emerging challenges in urban waste management in Tehran, Iran during the COVID-19 pandemic. Resour Conserv Recycl. 2020;162:1-2. https://doi.org/10.1016/j.resco nrec.2020.105051.

106. Zhou L, Li F, Wu S, Zhou M. 'School's out, but class' on', the largest online education in the world today: taking China's practical exploration during the COVID-19 epidemic prevention and control as an example. Best Evid Chin Edu. 2020;4(2):501-19. https://doi.org/10.15354/bece.20.ar023.

Publisher's Note Springer Nature remains neutral with regard to jurisdictional claims in published maps and institutional affiliations. 